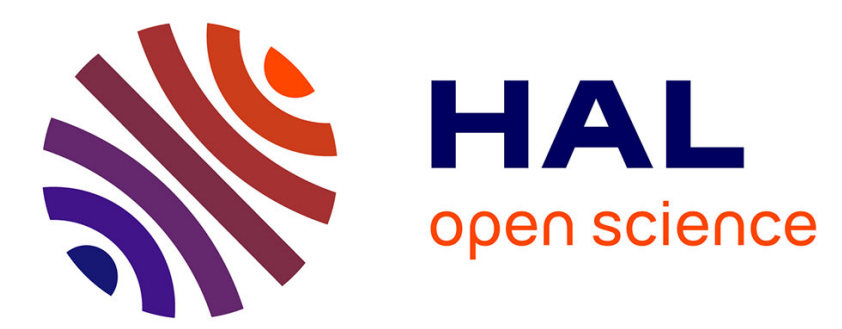

\title{
Fighting Locusts Together: Pest Control and the Birth of Soviet Development Aid, 1920-1939
}

\author{
Etienne Forestier-Peyrat
}

\section{To cite this version:}

Etienne Forestier-Peyrat. Fighting Locusts Together: Pest Control and the Birth of Soviet Development Aid, 1920-1939. Global Environment, 2014, 7 (2), pp.536 - 571. 10.3197/ge.2014.070211. halshs-01783386

\section{HAL Id: halshs-01783386 \\ https://shs.hal.science/halshs-01783386}

Submitted on 18 May 2018

HAL is a multi-disciplinary open access archive for the deposit and dissemination of scientific research documents, whether they are published or not. The documents may come from teaching and research institutions in France or abroad, or from public or private research centers.
L'archive ouverte pluridisciplinaire HAL, est destinée au dépôt et à la diffusion de documents scientifiques de niveau recherche, publiés ou non, émanant des établissements d'enseignement et de recherche français ou étrangers, des laboratoires publics ou privés. 


\section{Fighting Locusts Together: Pest Control and the Birth of Soviet Development Aid, 1920-1939}

\section{Etienne Forestier-Peyrat}

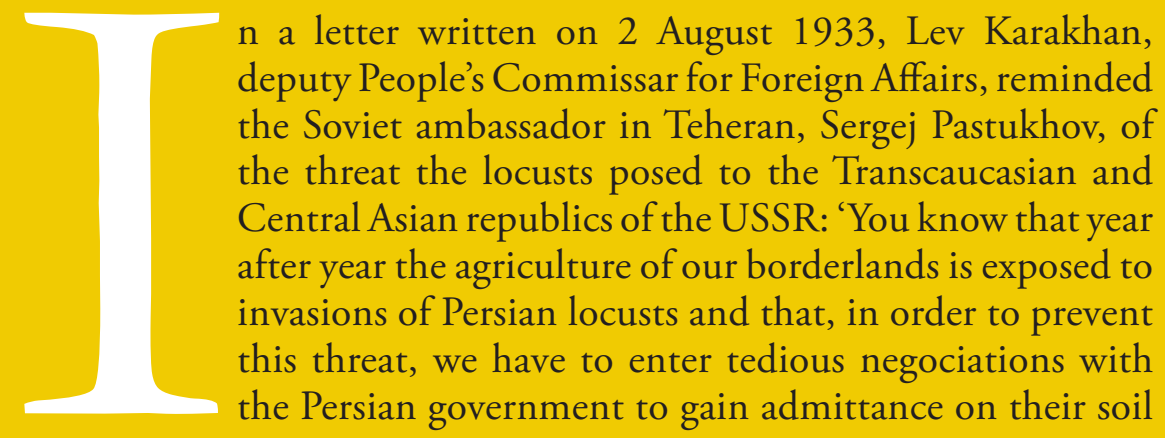

n a letter written on 2 August 1933, Lev Karakhan, deputy People's Commissar for Foreign Affairs, reminded the Soviet ambassador in Teheran, Sergej Pastukhov, of Central Asian republics of the USSR: 'You know that year after year the agriculture of our borderlands is exposed to invasions of Persian locusts and that, in order to prevent this threat, we have to enter tedious negociations with the Persian government to gain admittance on their soil

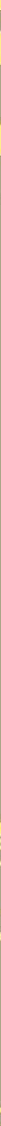


for our [anti-locust] expeditions'. ${ }^{1}$ Locust pests are one of the most ancient threats to South Caucasian agriculture, as they are in many other Middle Eastern and Mediterranean regions. ${ }^{2}$ Struggle against these pests, though, did not enter the realm of public policies in the region until the late nineteenth century. Of the three empires bordering on the Caucasus, Russia and the Ottoman Empire developed a set of measures, while Persia lagged behind. In Tsarist Russia, locust control was connected to settlement policies on the outskirts of the empire and stood alongside the fight against malaria, nomadic onslaughts, aridity and phylloxera. ${ }^{3}$ In the Ottoman Empire, progressive development led to a Provisional Locust Act passed on 14 November 1912, which established ad hoc structures in the provinces, under control of the Ministry of Agriculture. ${ }^{4}$

The ascent of the Bolsheviks in Russia, and the communist conquest of the Caucasus in 1920-1921, opened a new era in locust management. Agricultural pest control became a major priority for the new regime on three grounds. Ideologically, agricultural progress

${ }^{1}$ Letter from Karakhan to Pastukhov, 2 Aug. 1933, in F.P. Polia et al. (eds) Dokumenty vneshnej politiky SSSR, (Moscow: Gospolitizdat, 1970) Vol. 15, pp. 474-6.

${ }^{2}$ The case of Cyprus has been particularly well studied for the medieval and modern period: Ronald Jennings, 'The Locust Problem in Cyprus', Bulletin of the School of Oriental and African Studies 51 (1988): 279-313; Gilles Veinstein, 'Sur les sauterelles à Chypre, en Thrace et en Macédoine à l'époque ottomane', in I. Baldauf and S. Faroqhi (eds) Armağan: Festschrift für Andreas Tietze (Prague: Enigma, 1994).

${ }^{3}$ For the Caucasus, see S.A. Melik Sarkisjan, Muganskaja step'. Estestvenno-istoricheskij i sel'sko-khozjajstvennyj ocherk, pp. 34-6, Saint-Petersburg: Izdanie otdela zemel'nykh uluchshenij, 1897; Russian sectants were an important part of the settler population in the 1880s-90s and bore the brunt of the difficult acclimatisation: Nicholas B. Breyfogle, Heretics and Colonizers. Forging Russia's Empire in the South Caucasus (Ithaca; London: Cornell University Press, 2005) pp. 87-127.

${ }^{4}$ Çekirge Kânun-1 Muvakkat, see Ertan Gökmen, 'Batı Anadolu'da çekirge felâketi (1850-1915), Belleten. Türk Tarih Kurumu 74 / 269 (2010): 127-80; Meltem Toksöz, Nomads, Migrants, and Cotton in the Eastern Mediterranean: The Making of the Adana-Mersin Region, 1850-1908 (Leiden: Brill, 2010). 
and the subjugation of nature was a key feature of communism and the deep sense of socio-economic backwardness that accompanied the Bolsheviks in their rise to power only intensified this. In internal politics, locust pests constituted a serious threat to the border republics of the Soviet Union, especially Armenia, Azerbaijan, Turkmenistan and Uzbekistan, as they brought about food shortages and unrests. Suppressing the locust threat was thus part of a social contract made by the Bolsheviks in these peripheries. Doing so at the same time allowed political control over the countryside through mass campaigns and administrative structures. Finally, locust management had also to do with international relations, since locusts know no political borders and migrate according to various subcontinental patterns in a wide Middle-Eastern crescent that spreads from Eastern Africa to Central Asia and India. Logically, locust control became a favourite topic for Soviet diplomats in their relations with Iran and Afghanistan, but also with Mongolia and the quasiautonomous Xinjiang in the 1920s-1930s.

The common point to all these dimensions was the idea that the locusts were 'foreign' intruders and that the Soviet border had to be defended against their attacks. However, state and Party officials involved in the policy-making process diverged on the measures to adopt. Analytically, two paradigms can be distinguished, even though they frequently overlapped. On the one hand, some argued that the Soviet Union should focus on unilateral and internal measures to protect its territory and turn its Southern political borders into environmental ones as well. This idea was clearly influenced by the general isolationist mood and fear of foreign interventions prevailing at the time. The opposite stance claimed that this environmental 'iron curtain' was nothing short of an illusion and called for partnerships to be built with Middle Eastern and Asian neighbour states, in order jointly to manage locust plagues. As the 1920 s went on, this second view progressively gained the upper hand. Scientific factors played a role in this evolution, since the lifecycle of the locusts, the determinants of their transition from a lone stage, when they cause no harm, to a gregarious stage, when they grow, often change colour and become voracious plant-eaters, was researched by 
numerous entomologists. ${ }^{5}$ Their regional and continental geography was also thoroughly inquired into at the numerous research centres established at the time. The International Institute of Agriculture, established in 1905 in Rome, played no small role in the growing interconnection of locust experts around the globe. ${ }^{6}$

Another dimension was, however, as important as scientific advances. With the fall of the Ottoman Empire, the Middle East was partially shared between France and Great Britain. New states were created and locust management became an issue which attracted great attention among those colonial powers. For Soviet leaders, French and British activism in the field concealed political ambitions and was part of the cordon sanitaire against communism. Building an anti-acridian cum anti-imperialist international network logically became a priority for Soviet diplomats, from the late 1920s, as one of the ways to break political isolation. ${ }^{7}$ This paper argues that this project was part of the birth of Soviet development aid. Whereas this aid has been traditionally seen as a child of the Cold War and a means to win over the Third World, it seems important to reassess the place of the interwar period. What the post-1945 period actually achieved was the globalisation of policies developed along the

${ }^{5}$ A general picture of scientific evolutions in the first half of the twentieth century is given in a classic work: Boris Uvarov, Grasshoppers and Locusts. A Handbook of General Acridology, Vol. 1: Anatomy, Physiology, Development, Phase Polymorphism, Introduction to Taxonomy (Cambridge: Cambridge University Press, 1966).

${ }^{6}$ The Institute replaced in 1905 the International Agricultural Commission created in 1889, and greatly contributed to the internationalisation of agricultural know-how. See Luciano Tosi, Alle Origini della FAO. Le relazioni tra l'Istituto Internazionale di Agricoltura e la Società delle Nazioni (Milano: FrancoAngeli Storia, 1989); Asher Hobson, The International Institute of Agriculture: An Historical and Critical Analysis of its Organization, Activities and Policies of Administration (Berkeley: University of California Press, 1931).

${ }^{7}$ Jon Jacobson, When the Soviets Entered World Politics (Berkeley; Los Angeles; London: University of California Press, 1994) pp. 51-80; Harish Kapur, Soviet Russia and Asia, 1917-1927. A Study of Soviet Policy Towards Turkey, Iran, and Afghanistan (Geneva: Geneva Graduate Institute of International Studies, 1966); Mikhail Volodarsky, The Soviet Union and its Southern Neighbours, Iran and Afghanistan, 1917-1933 (Ilford; Portland: Frank Cass \& Co., 1994). 
Soviet borders before the Second World War. Policies used in the 1920s-1930s to influence Kemalist Turkey and Pahlavi Persia, in the context of a trilateral modernising emulation, were extended to faroff countries. ${ }^{8}$ A case study of the Azerbaijani border between Persia and the USSR will serve as the testing ground for my argument.

\section{'Defending the border': Reframing locusts as foreign intruders}

World War One saw the Caucasus as one of the main front-lines in the conflict against the Ottoman Empire. Even though public attention was focused on military operations, locusts remained a surprisingly important concern in the region. On both sides of the border, the war exhausted agricultural and industrial resources and productivity was to be raised as part of the war effort. ${ }^{9}$ As the Russian Caucasus was more and more required to be self-sufficient, any attack against its agriculture was reconstrued as a state issue and part of the war system. ${ }^{10}$ Locusts and other agricultural pests were now to be dealt with for military and strategic reasons, as cotton and food were central for waging the war. Insects being, to paraphrase Carl Johansen, 'the only animals giving man a real battle of supremacy', this identification was relatively easy. ${ }^{11}$ The fact that pests and insects served often as metaphors to describe the enemy in the period inaugurated by World War One contributed to this awareness. ${ }^{12}$ The

${ }^{8}$ Celal Metin, Emperyalist Çă̆da Modernleşme. Türk Modernleşmesi ve Iran (1800-1941), Ankara: Phoenix, 2011, pp. 287-308; Adeeb Khalid, 'Backwardness and the Quest for Civilization: Early Soviet Central Asia in Comparative Perspective', Slavic Review 65 / 2 (2006): 231-251.

9 Peter Gatrell, Russia's First World War. A Social and Economic History (Edinburgh: Pearson Education, 2005) pp. 108-31 and 154-175.

${ }_{10}$ This holds also true for World War Two, with numerous expeditions led by the Allies in the broad Middle East. See for example, Alan S. Milward, War, Economy and Society, 1939-1945 (Berkeley; Los Angeles: University of California Press, 1979) pp. 292-293.

${ }^{11}$ See his article, 'Principles of Insect Control', in R.E. Pfadt (ed.) Fundamentals of Applied Entomology, pp. 171-181 (New York: Macmillan, 1971).

${ }^{12}$ Edmund P. Russell, 'Speaking of Annihilation: Mobilizing for War Against 
Russian military presence in north-western Persia that resulted from the Persian Revolution of 1906-1911 was accompanied by an increased presence of technical and military staff. Concrete observations about locusts in Iran were made and geographical connections became clearer. Russian observers and entomologists formulated hypotheses about continental migrations of locusts. More generally, World War One corresponded in the Middle East and Northern Africa with a period of intense locust invasions.

The Ottoman Empire was the hardest struck, with a first invasion of Moroccan locust in 1914 followed by the Sudanese locust in 1915 . Long debates on a locust annihilation Act took place in the Ottoman Chamber of Deputies as early as June $1914 .{ }^{13}$ Insect pests threatened to disturb war operations, as well as food supply in the region, and had to be eliminated. The Ministry of War created labour battalions to fight the scourge. Locusts nonetheless caused heavy losses in the Arab provinces at the time, contributing to a disruption in the regional economy. ${ }^{14}$ Syria and Palestine suffered in the first rank, and 1915 was dubbed the 'Year of the Locust' with a dispiriting impact on Ottoman soldiers. ${ }^{15}$ Cemal Pasha, commander of the Fourth Ottoman Army, wrote: 'Being badly upset by this natural disaster, we were pessimistically thinking how we would spend this year'. ${ }^{16}$ These

Human and Insect Enemies, 1914-1945', Journal of American History 82 / 4 (1996): 1505-1529 and War and Nature. Fighting Humans and Insects from World War I to Silent Spring (Cambridge: Cambridge University Press, 2001).

${ }^{13}$ For debates on the locust annihilation bill (çekirge itlafı hakkında kanun layihası) see 'Onsekizinci Inikad. 7 Haziran 1330 (1914)', Meclisi Mebusan Zabıt Ceridesi, Term 3, Year of Session 1, Vol. 1, TBMM Basımevi, 1991, pp. 388-90, also pp. 225-39, 247-8.

${ }^{14}$ Kurt Floericke, Heuschrecken und Libellen (Stuttgart: Kosmos, 1922) pp. 9-10.

${ }^{15}$ Ihsan et-Tercüman, Çekirge yılı (Kudüs 1915-1916) (Istanbul: Klasik Yayınları, 2012). Original edition, Salim Tamari, Year of the Locust. A Soldier's Diary and the Erasure of Palestinés Ottoman Past (Berkeley; Los Angeles; London: University of California Press, 2011); 'Onbirinci Inikad. 10 Kanunevvel 1331 (1915)', Meclisi Mebusan Zabıt Ceridesi, Term 3, Year of Session 2, Vol. 1, TBMM Basımevi, 1991, p. 214.

${ }^{16}$ Cemal Paşa, Hatırât, Istanbul: Arma Yayınevi, 1996, quoted in Hikmet Özdemir, The Ottoman Army 1914-1918. Disease and Death on the Battlefield (Salt Lake City: University of Utah Press, 2008) p. 156. 
events were observed with mixed satisfaction and anxiousness in the Russian Caucasus, where newspapers closely followed developments in the field and were on the lookout for signs of invasion. ${ }^{17}$ World War One, in this manner, started the process by which the locust began to be perceived as an alien threat coming from over the border.

It was not incidentally that the International Agricultural Institute decided in 1916 to publish a handbook on locust management in several countries. ${ }^{18}$ Even though Russia itself was not affected by the Year of the Locust, Caucasian authorities were sufficiently disquieted to order a reorganisation of the locust prevention system. Two Offices for the prevention of agricultural pests were created in 1916, one based in Tiflis, the other in Baku. ${ }^{19}$ They concentrated both scientific and operational competences, and were expected to bridge the gap between the two dimensions, which had been criticised in the 1910s. The Office notably tried to collect data on the historical cartography of the locust, to develop predictive capacities. It was also expected to propagate knowledge in the population with booklets, posters and a dedicated museum on agricultural pests. The war, however, left it with severely restricted means. The period of revolutions and independences in 1917-1920 witnessed a general collapse of agriculture and the economy at large. Procedures worked out to fight the locusts were almost entirely abandoned in view of the troubled political situation. Geographical factors contributed to this abandonment at the time of independences. Locusts were concentrated in steppe border areas between the three Caucasian republics and along the border with Iran, where military operations happened and insecurity was permanent, preventing anti-acridian works.

${ }^{17}$ See for example, 'Bor'ba s vrediteljami v Zakavkazje', Kavkazskoe slovo 122 (31 May -13 June 1915): 5.

${ }^{18}$ Bureau des renseignements agricoles et des maladies des plantes, La lutte contre les sauterelles dans les différents pays (Rome: Institut International d'Agriculture, 1916).

${ }^{19}$ Report on plant protection in Georgia, presented by Nagornyj, 31 Mar. 1924, Trudy pervogo s"ezda Narkomzemov ZSFSR v gorode Tiflis, 30 marta-5 aprelja 1924 (Stenograficheskij otchet) (Tiflis: Izdanie Narkomzema Gruzii, 1924) pp. 3-4. 
In April 1920, as the Bolsheviks staged their coup in Azerbaijan, the economic situation of the country indicated a steep decline from the pre-war levels. Livestock amounted to only sixty per cent of what it had been in 1913. In the Mugan, a mere 24 out of 150 irrigation canals still worked. Slightly more than 8,000 desiatins were irrigated, against 102,000 in $1913 .{ }^{20}$ Civil war destruction and lack of maintenance combined with strong locust destruction. More than 200,000 desiatins fell prey to pests in 1920 in all Azerbaijan, especially in southern borderlands. The Azerbaijani Revolutionary Committee took swift measures against the locust pests, which threatened a new famine and a further decline of agricultural production. As Soviet Russia pressed the sister republic to supply it with food for starving Russians and Ukrainians, Azerbaijan was under great pressure. Soviet officials began to draft anti-acridian plans at the end of 1920. The Sovietisation of Armenia at the beginning of December 1920 opened a tentative opportunity for cooperation but the protracted Dashnak insurrection in Zangezur, the border region most concerned by the locusts, prevented cooperation until 1922. ${ }^{21}$ Even in later years, the internal administrative partition of the regions threatened by locusts would prove an occasional hurdle to well-coordinated action.

The Bolshevik reframing of locust pests as a foreign threat menacing Soviet borders merged two dimensions. On the one hand was the evolution of scientific knowledge to better grasp the migratory dimension of the locusts, its biological and ecological determinants and the peculiarities of each species within the Caelifera sub-order. It was in 1920-1921 that the Russian émigré Uvarov submitted his first hypotheses on phase polymorphisms and determinants of lo-

20 This Russian unit of measure progressively abandoned in the 1920s was equal to 2.7 acres; Tretij Sozyv Vseazerbajdzhanskogo s"ezda Sovetov rabochikh, krestjanskikh, krasnoarmejskikh i matrosskikh deputatov. Protokoly i strenograficheskij otchet, Baku, 1924, pp. 130-132; see also the report for the Council of Labour and Defence (STO), which established a general assessment of the situation in the early 1920s in Southern Azerbaijan. Mikhail Avdeev, Mugan' i Sal'janskaja step.'Naselenie-Zemlepol'zovanieVodnoe khozjajstvo (Baku: Komissija po obsledovaniju Mugani, 1927).

21 'Migliorata situazione economica in Armenia', Oriente Moderno 2 / 3, (Aug. 1922): 172 . 
cust migrations. ${ }^{22}$ In October 1920, the International Agricultural Institute staged its first international conference on interstate locust cooperation..$^{23}$ On the other hand, the ideology of war communism and bolshevism, which depicted Soviet Russia as a beleaguered country, integrated the locust factor in its rhetoric. Quite tellingly, a decree by the Azeri Sovnarkom proclaimed locust control a 'military task' in October 1921, in direct continuity from the civil war. ${ }^{24}$ Science met politics to produce a different perception and new modes of managing the locust pests, clearly conceived as border problems.

\section{Locust control and Soviet mass mobilisation}

Soviet locust management in the border republics of the Caucasus and Central Asia was tightly connected to the general project of transforming and modernising the countryside. Development was first and foremost an internal project. However, ecological interdependence meant all measures taken on Soviet soil could be reduced to nil if nothing was done in Iran. At the Iranian-Azeri border, the Mugan steppe constituted an environmental unit divided by the border and numerous locusts nested in Persian Mugan..$^{25}$ Thus, mass mobilisation on the Soviet side of the border surreptitiously influenced developments in Iran in the early 1920s. This influence could be felt during the entire process of locust control, which followed a similar pattern, year after year.

${ }^{22}$ Uvarov, 'A revision of the genus Locusta, L. (= Pachytylus, Fieb.), with a new theory as to the periodicity and migrations of locusts', Bulletin of Entomological Research 12 (1921): 135-163.

${ }^{23}$ Institut International d'Agriculture, Actes de la Conférence Internationale pour l'organisation de la lutte contre les sauterelles (Rome, 28-31 octobre 1920) (Rome: Institut International d'Agriculture, 1921).

${ }^{24}$ L.P. Semenov (ed.) Ocherk bor'by s sarancheiu v Azerbajdzhane $i$ kampanija bor'by 1921-1922 g. (Baku: Narkomvnudel ASSR, 1922) pp. 42-4.

${ }^{25}$ On this aspect, Ernst Eckenberger, Gliederung der Mugan-, Mil- und Karabachsteppe Transkaukasiens (Frankfurt an der Oder: Richard Rischke, 1936); V.R. Volobuev, Mugan' i Sal'janskaja step': pochvenno-meliorativnyj ocherk (Izdatel'stvo Akademii Nauk Azerbajdzhanskoj SSR, 1951). 
In the Caucasus, Soviet Azerbaijan and Iranian border areas were the main regions concerned, even though Armenia and Georgia frequently had to tackle locust invasions. The year 1924 can serve as an example of the way locust campaigns unfolded. In September-November 1923, expeditions were sent in southern and southwestern Azerbaijan, where locusts nested, to scout the countryside and localise locust podds, their concentration and all ecological factors which could be of interest. Whenever possible, teams were also dispatched to Persia, in order to reconnoitre border areas. If locusts could freely develop in the Persian Mugan, their later migration in spring would ruin all efforts undertaken on Soviet soil. The logic of biological units did not correspond to political borders and demanded cross-border action. Intelligence was transmitted and concentrated in the Azeri Organisation for Plant Protection (OZRA) by December 1923. The OZRA calculated the human, material and financial means needed to annihilate the locusts, on both Soviet and Persian soils. In early January 1924, Bunyat-Zade, Azeri Commissar for Agriculture, declared that 100,000 desiatins were contaminated and should be treated preventively. This was a huge area, and scheduled expenses reached 200,000 rubles for annihilation in Azerbaijan and $100-150,000$ in Persia. ${ }^{26}$ After complicated budgetary negotiations, the campaign to annihilate locust nests began in April, at the time when locust podds hatched. The campaign relied upon peasant forced work. They were engaged in mechanical destruction of podds and young locusts, by different means. As the 1920s went on, they were increasingly supported by aeroplanes, used to spread poison and insecticides on contaminated areas. ${ }^{27}$ These works, if undertaken in time, could destroy a majority of the locusts.

However, not all locust podds on Soviet land could be treated and exterminated, due to organisational and technical flaws. More prob-

26 'Ocherednye zadachi Narkomzema (beseda s tov. Bunjat-Zade)', Bakinskij Rabochij 7 / 1030, (10 Jan. 1924): 3.

${ }^{27}$ Letter from the Georgian OZRA to the Transcaucasian Sovnarkom, 18 Sept. 1928, Sakartvelos uakhlesi istoriis tsentraluri arkivi (Central State Archive for Contemporary History of Georgia, SUITsA), f. 617, op. 1, d. 2361, 11. 7-10. 
lematic yet was the migration of locusts from across the border. These migrations were practically impossible to predict, in the absence of any information exchange with the Persian government on the situation in central and southern Persia. Soviet officials and entomologists had reliable intelligence only about the limited border strip they could explore themselves, about twenty versts into Iranian territory. There was thus a great deal of uncertainty in their action. ${ }^{28}$ All of a sudden, swarms of locusts could cross the border, in the Mugan steppe or westward along the Arax river. The Soviet regime had now to carry on with a different type of action, a type in which it was elsewhere well experienced, a short-term high-intensity campaign, whose aim was to stop the invasion. ${ }^{29}$ Whereas the first type of campaign, exterminating eggs and young locusts, was expensive and time-consuming, the second phase involved fighting and killing adult locusts in a context of general panic. Depending on their species, adult locusts can exceed twenty centimetres in length. They are particularly voracious and able to ravage an entire field in a few minutes.

Soviet authorities partially fostered this fear, in order to mobilise and unite the population around the state and Party. An example is the newspaper Kommunist's headline on 14 May 1924, when the invasion from Persia was announced. A giant locust, standing on its hind legs, threatened the reader with a scythe featuring skulls and crossbones. Vultures hovered over the desert steppe that stretched in the background. A single word topped this cartoon: 'The locusts!'. ${ }^{30}$ The article that followed, entitled'On the locust front', offered an

${ }^{28}$ Forecasting migrant insect pests remains an important problem in many regions: see R.K. Day and J.D. Knight 'Operational Aspects of Forecasting Migrant Insect Pests', in V.A. Drake and A.G. Gatehouse (eds) Insect Migration. Tracking Resources through Space and Time, pp. 323-34 (Cambridge: Cambridge University Press, 1995); I.P. Woiwood, D.R. Reynolds and C.D. Thomas, 'Introduction and Overview', in I.P. Woiwod, D.R. Reynolds and C.D. Thomas (eds) Insect Movement: Mechanisms and Consequences, pp. 1-18 (Wallingford; New York: CABI Publishing, 2001).

${ }^{29}$ Peter Kenez, The Birth of the Propaganda State. Soviet Methods of Mass Mobilisation, 1917-1929 (Cambridge; New York: Cambridge University Press, 1985).

30 'Çekirtge cebhesinde', Kommunist 104 / 1104 (14 May 1924): 1. 
Figure 1: Front-page cartoon, 'The locusts!', Kommunist, 15 May 1924, p. 1

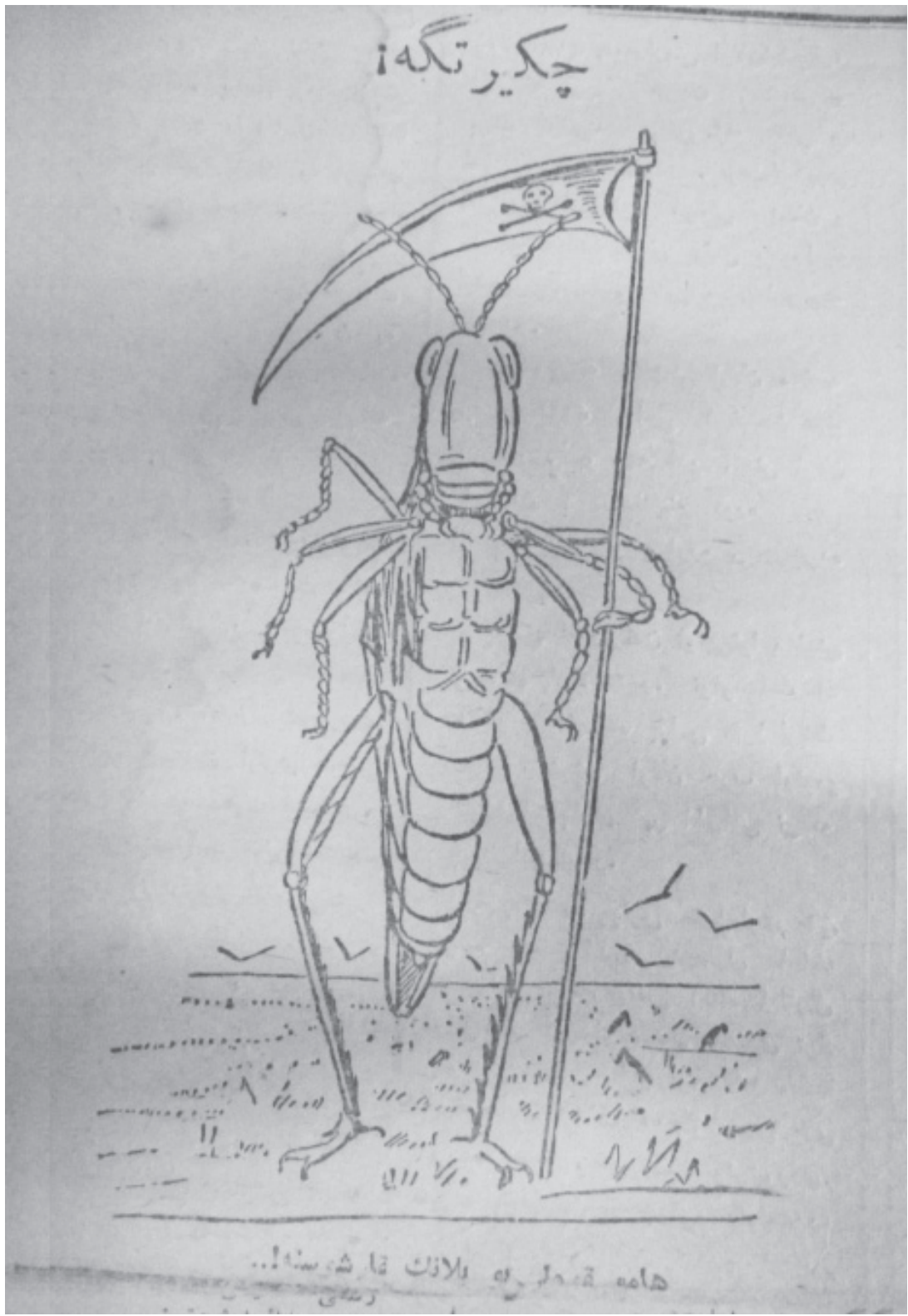


example of communist zeal and diligence in the figure of comrade Ibrahimov, who supervised the struggle in the Ağdam region. The campaign then went on with tens of thousands peasants mobilised at its peak, even though desertion was rife. Instructors from the OZRA supervised the work, helped by local officials and policemen. In June 1924, Bunyat-Zade toured the districts affected by the locust, meting out punishments and awards. ${ }^{31}$ For Azeri leaders, the locust campaign was an occasion to turn to the masses and the countryside, as current slogans had it. Mechanical means such as extermination by fumigation, poisoned baits, water canals where locusts were trapped and metal boards were still overwhelmingly used. Newspapers followed day after day the progress of anti-acridian works and offered numerous articles. The Transcaucasian government and Regional Party Committee also received secret reports on the situation.

Despite the traditional character of fighting methods implemented in the early 1920s, the use of aeroplanes and new insecticides was the object of hot debate in the late 1920s and early 1930s. Aeroplanes had numerous supporters, who stuck to almost political rationales for legitimating their use. An aircraft was a symbol of modernity, coterminous with efficiency. ${ }^{32}$ All-out use of aircraft was a stimulus to industrialisation and simultaneously served defence purposes. In this border region, who could have doubted that planes were double-use, since they enabled the Soviet Union to undertake reconnaissance work in Persia over the border. The use of aircraft for operations in Persia itself was at first rejected by Persian officials and incidents still happened, well into the 1930s. However, some opponents noted that planes were definitely not a cure-all. Ideology should not blind practicality and planes could not be used everywhere. In the Persian part of the Mugan, the steep and

31 'Bor'ba s saranchej', Bakinskij Rabochij 103 / 1126 (9 May 1924): 3; 'Polnyj uspekh bor'by na saranchevom fronte', Bakinskij Rabochij 128 / 1151 (9 June 1924): 1.

${ }^{32}$ On the question of innovation and efficiency, with the sometimes higher efficiency of older instruments, see David Edgerton, The Shock of the Old: Technology and Global History since 1900 (London: Profile Books, 2006), passim; a glimpse in the Soviet public stance in OBV, Aviatsija v bor'be s vrediteljami sel'skogo i lesnogo khozjajstva (Moscow: Sel'khozgiz, 1932). 
rugged landscape caused heavy waste when planes spread pesticides. The weather sometimes prevented them from taking off, when haze or sand storms set in. If no back-up option had been prepared, the expedition was left powerless. The use of insecticide, pesticide and poisoned baits did not raise so much passion and was not much debated. However, one could note, now and then, remarks about the potential danger of indiscriminately using poisoned substances. Paris green, a copper and arsenic compound, was a favourite among Soviet officials, but could cause severe water pollution and destruction of vegetation. ${ }^{33}$ As in other parts of the Middle East, peasants' complaints often lay at the basis of such qualms. ${ }^{34}$ Some institutions suggested that massive recourse to pesticide was evidence of the deficiencies of Soviet applied science, which had not been able to devise 'intelligent' remedies. ${ }^{35}$

Each year, a decree was adopted by the Transcaucasian Central Executive Committee and Sovnarkom to appoint a locust-struggle plenipotentiary, which was then confirmed by republican authorities. The decree was usually stern and martial in tone, pointing to the tremendous danger set by locusts in the region. The plenipotentiary had very broad competences, which embraced general police for the time of the campaign in districts concerned. He wielded wide powers in the administrative and political apparatus itself. When Erzinkjan, Transcaucasian People's Commissar for Agriculture, was appointed plenipotentiary in 1930, he could

Submit to administrative measures, arrest and bring to trial all officials, guilty of untimely or inaccurate completion of his orders, or having tolerated deficiencies of any kind, likely to have an impact on the success of the antiacridian campaign. ${ }^{36}$

${ }^{33}$ N.A. Kholodkovskij, Kurs entomologii teoreticheskoj i prikladnoj, Vol. 2, pp. 66-7 (Moscow: Gosizdatel'stvo, 1929).

${ }^{34}$ For such complaints about cattle losses due to poisoned grain in Iran, see Sir G.A. Richardson, Report on the Current Locust Situation in the Bandar Abbas District up to May 1930, 28 June 1930, NHMA, AL2/100.

${ }^{35}$ See the veiled criticism of the Transcaucasian representation in a letter to the Transcaucasian government, 6 June 1928, SUITsA, f. 617, op. 1, d. 2203, 11. 1-3.

${ }^{36}$ Protocol No. 25, Session of the Transcaucasian Central Executive Committee's Presidium, 3 June 1930, SUITsA, f. 607, op. 1, d. 2616, 1. 3. 
Such exorbitant powers were necessitated by the disparate interests of local officials, who tried to defend above all their own districts, at the cost of the general coherence of the campaign. The fact that locust destruction threatened an inability to fulfil grain requirements and production targets played no small role in this occasional unwillingness to implement central decisions, whenever they contradicted local interests. In Azerbaijan, the first plenipotentiary appointed in February 1922, Mir Djafar Bagirov, was the head of the local Cheka, and used this position in order to tighten his grip on countryside officials, as he was already busy building his own power base before becoming first secretary of the Azery Communist Party from 1938 to $1953 .{ }^{37}$ Major political players were conscious of the profits they could draw from the locust campaigns.

Coercion associated with anti-acridian operations was a very effective but not much advertised aspect of these campaigns. Rather, Soviet officials were fond of presenting locust-fighting as a central element of the social contract in the region. As M.S. Ordubadi, an editor of Kommunist wrote: 'Azeri peasants should unite around state institutions and deal a decisive stroke to the enemy'. ${ }^{38} \mathrm{~A}$ central problem in this respect was the resort to unpaid labour for preventive and reactive operations. Despite strong repudiations, Azeri officials were conscious that resort to unpaid labour (trudguzhpovinnost), by nature a form of tax, was unpopular among peasants in the border regions. ${ }^{39}$ In 1925, a harsh winter and natural catastrophies forced them to renounce unpaid labour so as to avoid an all-out

37 See the protocol of the Azrevkom, 13 Feb. 1922, reproduced in Ataxan Paşayev (ed.) Azerbaycan inqilab komitesi ve xalq komissarlar Sovet iclaslarmın protokolları (1920-1922ci iller) (Baku, Azerbaycan Respublikasinin Milli Arxiv Idaresi/Çaşığlu neşriyyatı, 2009) pp. 352-355; on Bagirov's position at the time and personal ties with Beria, see Amy Knight, Beria. Stalin's First Lieutenant (Princeton: Princeton University Press, 1993) pp. 19-23.

${ }^{38}$ Elmar Məhərrəmov, Gazeta Kommunist $i$ voprosy vosstanovlenija sel'skogo khozjajstva (Baku: Nurlan, 2004) p. 242.

39 Alexis Berelovitch and V. Danilov, Sovetskaja derevnja glazami VChK-OGPU-NKVD, 1918-1939, Vol.: 1918-1922 (Moscow: ROSSPEN, 2000) p. 630. 
rebellion. ${ }^{40}$ Mustafa Chokaev, a nationalist emigré from Central Asia, termed unpaid work in cotton fields a modern serfdom. It appeared as a remnant of the Ancien Régime and Soviet authorities were keen to justify it by clearly linking it to environmental issues. A rational discourse was developed to legitimate collective voluntary work in order to master natural challenges, such as floods, pests, diseases or earthquakes. As all of these natural hazards happened in the region, they were lumped together in a depiction of nature as an enemy to be defeated, along with Dashnaks, imperialists and others. Whereas Ancien Régime corvée embodied exploitation, Bolshevik corvée originated in natural constraints. ${ }^{41}$ The chronic deficit in workforce was also mentioned in secret reports. ${ }^{42}$ Discontent seems to have risen after collectivisation. In 1930 and 1931, the Azeri and Transcaucasian Narkomzems militated in favour of paying the local labourers, to avoid serious unrest. It asked for 500,000 rubles in addition to the 1.2 million rubles already granted for the locust campaign, but the Transcaucasian Commissariat for Finance turned the request down on budgetary grounds. ${ }^{43}$

Locust campaigns were concentrated in time, but they came with permanent measures to educate the population. In almost all Eurasian cultures, locusts evoked religious and superstitious reactions. ${ }^{44}$ These reactions did not necessarily hinder pragmatic steps

${ }^{40}$ Letter from the Azeri Sovnarkom to the Transcaucasian Sovnarkom, 30 Mar. 1925, SUITsA, f. 617, op. 1, d. 468, 1. 26.

${ }^{41}$ For global comparisons and insights on the problem of forced labour, see Alessandro Stanziani (ed.) Le Travail contraint en Asie et en Europe, XVII'-XXe siècles (Paris: Editions de la MSH, 2010); see also Martin Thomas, Violence and Colonial Order. Police, Workers and Protest in the European Colonial Empires, 1918-1940 (Cambridge-New York: CUP, 2012) pp. 20-23 and passim.

${ }^{42}$ It was estimated in 1930 that 52,850 people were available for collective works in Mugan, with a deficit of around 24,000 people. Report of the special commission on the water problem in Mugan to the Azeri Sovnarkom, undated (June-July 1930), SUITsA, f. 617, op. 1, d. 117, 1. 10.

${ }^{43}$ Letter from the Narkomzem ZSFSR to the Transcaucasian Sovnarkom, 31 Jan. 1931, and answer from the Narkomfin ZSFSR to the Transcaucasian Sovnarkom, SUITsA, f. 617, op. 1, d. 5601, 1l. 3-4. and 8.

${ }^{44}$ For the Chinese case, see Raimund Theodor Kolb, Die ostasiatische Wan- 
to fight the locusts, but sometimes produced seemingly irrational behaviours in the peasant population. In Russia, it seems that the church was the main refuge in the face of locust invasions. Well into the 1920s, Russian peasants would ask the local pope to pray and deflect the invasion, much to the outrage of Soviet officials. ${ }^{45}$ In the Middle East, especially in Turkish and Persian-speaking areas from Eastern Anatolia to Afghanistan, superstition and folk customs thrived on locust-impelled terror. There existed, as the story went, a miraculous spring in Eastern Iran, probably Khorasan. If a particular bird drank the water taken from this spring, called 'locust water' (âb-i malakh), it would be converted into a ravenous locust-killer. ${ }^{46}$ In times of invasion, peasants would strive to get this water by all means. This medieval tradition was still very lively in early twentieth century Transcaucasia. For Soviet officials, it posed a threat as it maintained a link with the Iranian cultural area and Islamic traditions. The locusts thus gave an opportunity to push forward the struggle against superstition in the local population. Soviet officials expected that a success in locust management would be a sufficient miracle to convert the population to communism. They had their own holy texts in the form of an abundant literature, both in Russian and Azeri, concerning the scientific and modern approach to the locust. ${ }^{47}$ Newspapers were also active in popular agricultural

derheuschrecke und ihre Bekämpfung unter besondered Berücksichtigung der Ming- und Qing-Zeit (1368-1911) (Heidelberg, Edition Forum, 1996); and Yu Rongliang, 'Woguo lishishang dui zuowubingchonghai de yaowufangzhi gaikuang' [我國歷史上 對作物病蟲害的藥物防治概況], Nongye kaogu [农业 考古] 1 (1983): 212-221.

${ }^{45}$ A literary example of this popular mysticism in the fight against the locust can be found in R. Berezov and A. Glagolev, O popovskoj zabote, o saranche i o samolete (Moscow, ODVF, 1925), quoted in Scott W. Palmer, Dictatorship of the Air: Aviation Culture and the Fate of Modern Russia (Cambridge: Cambridge University Press, 2006) pp. 131-134.

${ }^{46}$ The bird in question was the rose coloured pastor (pastor roseus), according to Jean Deny, 'La légende de "l'eau des sauterelles" et de l'oiseau qui détruit ces insectes', Revue asiatique, (Apr.-June 1933): 323-340.

${ }^{47}$ As soon as spring 1921, a seven-page bilingual booklet was edited containing instructions on locust fighting: Çekirtge zerervericileri ile mübarize telimatı, Baku, Başsiyasimaarif'in neşriyyat texnika bölmesinin neşri, 1921. 
education. Interestingly, the Azeri-language newspaper Kommunist devoted far more space to agriculture than the Russian-language official newspaper in Azerbaijan, the Baku Worker. ${ }^{48}$

\section{From internal development to cross-border aid}

Locust management stood at the middle of debates related both to this internal process of socio-economic modernisation and issues of international cooperation. The republican and Transcaucasian budgets, chronically cash-stripped, relied heavily on financial transfers from the centre to finance anti-acridian campaigns. The yearly variations in the level of locust contamination and migrations created a serious problem in budgetary planning. Additional credits were demanded by Transcaucasian authorities as soon as the first estimates about soil contamination were available, in January-February each year. On 21 January 1930, for instance, the Georgian Narkomzem asked for 80,000 rubles, in addition of the 30,000 it already had for locust management. ${ }^{49}$ The argument for demanding federal support was twofold. On the one hand, Transcaucasian leaders argued that the Caucasus was part of the Soviet agricultural border system and that it prevented, by its action against the locusts in the borderlands, continental invasion further into Russia. An action that benefited all Soviet republics should logically be centrally-funded. The ZSFSR also backed requests lodged by Turkmenistan and Uzbekistan for federal support of their own locust campaigns. On the other hand, it was noted that, since Transcaucasia grew valuable crops that were processed elsewhere in USSR, its agriculture was a state concern and should be protected by Moscow. Both as a border region and a subtropical basis the ZSFSR should be shielded from the locust pest, at the central government's cost. These arguments were replicated by Azerbaijan, Georgia and Armenia in their negotiations with Tiflis.

${ }^{48}$ Elmar Məhərrəmov, Xalq Qəzeti yaranması və inkişafı tarixinden (Baku: Elm va tahsil, 2009) pp. 50-58 and 75.

${ }^{49}$ Letter from the Georgian Sovnarkom to the Transcaucasian Sovnarkom, 21 Jan. 1930, SUITsA, f. 617, op. 1, d. 4979, 1l. 1-2. 
Republics generally obtained additional means, though not to the level they expected. The situation was especially difficult in 19291931, when credits were sometimes refused outright. ${ }^{50}$

In the first three years after Sovietisation, until 1923, Azerbaijan was so destitute that all costs for the locust campaign were borne by the Russian Narkomzem. This led to heavy complications, as machinery and insecticides were bought in Russia then shipped to Azerbaijan, causing serious delays. Organisational problems piled up, since financial networks had barely recovered and transfers took time. Transcaucasian authorities had to send special emissaries to Moscow to quicken the pace. ${ }^{51}$ The locusts were admittedly a sound justification to get fast money. However, Moscow authorities obviously suspected Transcaucasian leaders of overdoing it and inflating the amounts required. Georgia was especially distrusted, since it was irregularly stricken by the locusts and could not provide consistent statistics on its financial needs. ${ }^{52}$ Moscow top officials also bore in mind the trial organised in summer 1923, where thirteen top officials of the Azeri anti-locust organisation had been condemned for embezzling the funds lavished on the locust campaign by the Russian Narkomzem..$^{53}$ True, Transcaucasian leaders could have answered that the accused were predominantly Russian. The Azeri OZRA was in a permanent situation of indebtedness, due to the expenses it had to bear before it was established they would be covered by central subsidies. This created complex situations, as the State Bank would refuse to lend more money to the OZRA unless it repaid accumulated debts. ${ }^{54}$

${ }^{50}$ In the case referred to above, the Georgian Commissariat for Agriculture was asked to displace funds from a budgetary title to another to meet locust expenses. SUITsA, f. 617, op. 1, d. 4979, 11. 5,8 and 12.

${ }^{51}$ Letter from the Azeri Narkomzem to the Transcaucasian Narkomzem, 5 Feb. 1923, SUITsA, f. 607, op. 1, d. 22, 11. 1-2.

${ }^{52}$ Letter from the Georgian Sovnarkom to the Transcaucasian Sovnarkom, 9 June 1928, SUITsA, f. 617, op. 1, d. 2426, 1. 2 ; Letter from the Georgian OZRA to the Transcaucasian Sovnarkom, 18 Sept. 1928, SUITsA, f. 617, op. 1, d. 2361, 1l. 7-10.

53 'Delo saranchevoj organizatsii', Zarja Vostoka 163 / 328, (18 July 1923): 4.

${ }^{54}$ Letter from the Azeri Narkomzem Vezirov to the Transcaucasian Sovnarkom, 23 Feb. 1931, SUITsA, f. 617, op. 1, d. 5601, 1. 22. 
In parallel with intra-federal negotiations and conflicts, the Soviet locust campaign also involved operations led on Iranian soil. Soviet requests for cooperation were generally turned down in the early 1920s and only very limited actions could be performed. 1924 marked a clear transformation, with claims by Azeri institutions about the necessity to push the locust campaign beyond the border, since Iranian territory was a major host of locusts..$^{5}$ The locust campaign, from now on, was not only an internal border issue, but also an international one. Small expeditions were sent to Iran in the reconnaissance phase. In February, the plenipotentiary of the Soviet Commissariat for Foreign Affairs entered into diplomatic contacts with the Persian government to negotiate entry for the anti-acridian expedition itself. ${ }^{56}$ It was generally sent for a month or two to the border region, but schedules could vary abruptly. In 1926, 45 Soviet technicians and experts were sent, coordinating the work of thirteen brigades with eleven men each. The expedition enjoyed the support of several vehicles, though not as many as expected, due to the reluctance of Armenia to provide some of its own. However, the expedition could act only in a limited thirty-verst strip. This was better than the ten to thirteen versts conceded in earlier years, but Soviet experts considered their work would become really useful only if they could penetrate $200-250$ versts into Iranian territory. ${ }^{57}$ As a whole, 20,000 hectares were treated in Iran in 1926 and the estimated budget for locust works in this country reached 279,000 rubles. The situation was the reverse of normal years, when the majority of works were completed on Soviet soil..$^{58}$ Bankrolling the locust

${ }^{55}$ Vtoroj Zakavkazskij s"ezd Sovetov 4-7 janvarja 1924. Stenograficheskij otchet, Tiflis, ZakTsIK, 1924, p. 171; '1928-inci ilde A.S.Ş. cumhuriyeti çegirqe eleyhine mubareze işleri', Iktisadi Habarlar 12 / 118, (Dec. 1928): 71-72.

${ }^{56}$ Draft decision of the Transcaucasian Sovnarkom on the locust campaign, 11 Feb. 1933, SUITsA, f. 617, op. 1, d. 6657, 11. 1-2.

${ }^{57}$ Report from the Azeri OZRA to the Azeri Narkomzem, 25 Feb. 1926, SUITsA, f. 617, op. 1, d. 890, 1. 8; see also Yaşar Abdullaev, 'ZSFSR v razvitii sovetsko-iranskikh otnoshenij (1922-1928 gg.)' (Ph.D. Thesis, Baku, AN ASSRInstitut Vostokovedenija, 1986), pp. 136-7.

${ }^{58}$ Letter from the Azeri Sovnarkom to the Transcaucasian Sovnarkom, 25 Feb. 1926, SUITsA, f. 617, op. 1, d. 890, 1. 1. 
campaign in Iran was a financial problem, since it involved finding hard currency, generally dollars or gold-rubles, to pay local expenses. ${ }^{59}$

Cooperating with Persia on the locust pest meant transfers at more than the practical level of extermination campaigns. It was also an opportunity to gain influence in the budding milieu of Iranian agricultural entrepreneurs, administrators and scientists, where Westernising influences were strong. The Soviet Union was to propose its own model for development. Since Iranian intellectual elites attributed a great importance to the practical utility of knowledge, fighting against agricultural pests was a favourable bridgehead for penetration $^{60}$. Two first attempts were made to advertise Soviet science and technics to a broad Iranian audience in 1923 and 1925, at important fairs held in Teheran. In November-December 1923, a first fair was organised in Teheran, where the Soviet Union was the only country represented. The ambassador Shumjatskij emphasised the importance of taking part to this fair in order to propagandise both the general economic situation of Soviet Russia and some industrial branches'. ${ }^{61}$ Even though Iranians were disappointed by the absence of other European countries, Soviet exhibits apparently sparked some curiosity. The chairman of the organising committee, Mohtashem os-Saltane, considered that Soviet agricultural machinery and manufactures were a model for Persia to emulate. Soviet staff, he stressed, had a positive attitude to technological and scientific transfer. ${ }^{62}$ A second exhibition opened in August-September 1925 , oriented towards agricultural machinery, where Soviet state

${ }^{59}$ Correspondence between Azeri and Transcaucasian organs on this aspect, May-June 1926, SUITsA, f. 617, op. 1, d. 1209, 1l. 1-6.

${ }^{60}$ For considerations on 'science as knowledge-practice' and priority given to biology, parasitology and geology at the time in Persia, see the work of Cyrus Schayegh, Who is Knowledgeable is Strong. Science, Class, and the Formation of Modern Iranian Society, 1900-1950 (Berkeley; Los Angeles; London: University of California Press, 2009) pp. 50-58 and 75.

${ }^{61}$ Letter from Shumjatskij to the Russian-Oriental Chamber of Trade, 18 June 1923, SUITsA, f. 617, op. 1, d. 198, 1. 29.

62 'Tegeranskaja sel'sko-khozjajstvennaja vystavka', Bakinskij Rabochij 286 / 1014 (18 Dec.1923): 3. 
trusts occupied the first place in quantitative terms, beyond British and American industries. ${ }^{63}$

This influence was also institutional, as Soviet diplomacy urged Iran to transform its administrative structure. Such a transformation was to bring Soviet and Iranian institutions of locust control closer together. In a private meeting with the Iranian Foreign Minister, Forughi, the Soviet ambassador Chernykh emphasised in May 1935 the inadequacy of Iranian structures for locust-fighting: 'The main problem is the disproportion between the scale of the scourge and the material resources provided by the Persian government to fight it'. ${ }^{64}$ It was not all about technique or science, but also organisation. Environmental cooperation was thus a factor in institutional transfer and contributed to the aforementioned mutual observation and influences between Turkey, Iran and the Soviet Union. Three aspects may be emphasised in Soviet behaviour toward Iran: influence in the training of agricultural managers, transformation of the state apparatus and creation of an 'epistemic community' through regular intercourse. ${ }^{65}$

First, the Soviet Embassy in Teheran welcomed the creation in Karaj, near Tehran, of an agricultural college (Medrese-ye Ali-ye Falâhat), designed to train a new agricultural elite, familiar with scientific and technical approaches. Karaj would hopefully train officials closer in mindset to their Soviet counterparts and more cooperative than older and more conservative ones. Karaj actually trained almost all Iranian managers involved in agriculture in the 1920s-1930s and greatly helped implement pest control in the country. Students were regularly sent to Persian Azerbaijan to take part to anti-acridian campaigns and have contacts with Russian experts. ${ }^{66}$ Soviet support for

${ }^{63}$ A.E. Ioffe, Mezhdunarodnye svjazi Sovetskoj nauki, tekhniki i kul'tury, 1917 1932 (Moscow: Nauka, 1975) pp. 363-364.

${ }^{64}$ Report from Chernykh on his meeting with Forughi, 28 May 1935, Y.V. Borisov et al. (eds) DVP SSSR, Vol. 17, 1973, pp. 356.

${ }^{65}$ Following the widely known concept coined by Peter Haas, 'Introduction: Epistemic Communities and International Policy Coordination', International Organization 46 / 1 (1992): 1-35.

${ }^{66}$ British consulate in Tabriz, Tabriz Locust Report for August 1931, undated, Natural History Museum Archives (NHMA), AL/2/100. 
the college translated into teacher exchanges and ties with the Azeri Agricultural Institute, but also gifts from Transcaucasian or central authorities, such as agricultural machinery in summer $1931 .{ }^{67} \mathrm{Nu}$ merous experts and teachers at the college had received their scientific training in the Russian Caucasus. Jalal Afshar, a founding father of Iranian entomology, studied in Tiflis and Moscow before World War One. When he came back to Iran in 1919, he worked first for the newly-established Pasteur Institute, then for the Ministry of Public Works. He began to teach entomology, zoology and epidemic control at Karaj in 1926 and created an entomological laboratory there. ${ }^{68}$ He was a great translator and populariser of foreign scientific knowledge on agricultural pests in the late 1930s, while insisting that Iranians should themselves become active producers of such knowledge. Among numerous works, he published the first entomological treaty in Persian, Hashar-i shenâsi (1937-1945).

The influence of Jalal Afshar not only appeared in the field of scientific knowledge, but also that of administrative evolutions. Agriculture still had no ministry of its own, which caused diplomatic difficulties in intergovernmental correspondence. Some progress was made since the late 1920s. On 22 July 1929, the Persian government agreed to create as a first step a locust office in the Ministry of Public Works. ${ }^{69}$ Soon after, the Majlis passed a law launching the first locust campaign in Iran. ${ }^{70}$ The new acridian office was instrumental in pushing legislation favouring anti-locust campaigns, such as the

${ }^{67}$ Report E 4069/151/34, 29 July 1931, R.M. Burrell and R.L. Jarman (eds) Iran Political Diaries Vol. 9: 1931-1934 (London: Archive Edition, 1997), p. 37; on the Azeri Agricultural Institute, located in Baku until 1929 then in Ganja, Bahadur Heydər Ibrahimov, Istorija veterinarii v Azerbajdzhane (s drevnikh vremen do nashikh dnei) (Baku: Elm, 1971) pp. 338-9.

${ }^{68}$ Cyrus Abivardi, Iranian Entomology, 2: Applied Entomology (Berlin; Heidelberg; New York: Springer, 2001) pp. 532-534.

${ }^{69}$ N.S. Shcherbinovskij, Pustynnaja sarancha shistotserka. Problema zashchity juzhnykh territorij SSSR ot vtorzhenija staj shistotserki, Moscow: Gosizdatel'stvo sel'sko-khozjajstvennoj literatury, 1952, p. 378-381.

${ }^{70}$ Reports E 195/195/34, 28 Dec. 1929, and E 472/195/34, Burrell and Jarman (eds) cit., Vol. 8: 1927-1930, pp. 416 and 511. 
suppression of customs tariffs on the import of pesticides. ${ }^{71}$ As the Soviet Union was the first buyer of Persian cotton and agricultural products, it also had numerous commercial representatives that exerted their own pressure on Persian counterparts. The joint company Perskhlopok, created in 1923, had branches in numerous towns in cotton-growing areas and played a role in the modernisation of this sector. ${ }^{72}$ Constant Soviet presence in the 1930 s achieved progressive extension of the locust office. In 1934, an Agricultural Department was formally created at the Ministry for National Economy. Mostafa Quli Khan Bayat became its first director, while Jalal Afshar was appointed as main scientific advisor. Bayat gained the right to sit in the Council of Ministers, despite his lower rank, testifying to the rising importance of agricultural issues, in both internal and external affairs. However, a full-fledged ministry for Agriculture was not instituted before September 1941. ${ }^{73}$

Thirdly, Soviet authorities insisted on organising bilateral conferences and technical meetings from the late 1920s on. Until its end in 1936, the Transcaucasian Federation played a key role in creating a regional dynamics between the Soviet Caucasus and Northern Iran, even though the Russian Narkomzem had a pretension to steer the entire collaboration process. Baku and Moscow were the two common venues for such conferences. In 1927, a joint commission on locust control in the Mugan steppe met in Moscow and insisted on technical cooperation between the two states in the $\mathrm{Mu}$ gan. The commission mingled technical, administrative and political debates, as demonstrated by its proceedings. ${ }^{74}$ In the early 1930 s, Soviet officials regularly took part in the locust committees set up

${ }^{71}$ Letter of the German legation in Teheran to the German Foreign Ministry, 5 Sept. 1930, Politisches Archiv des Auwärtigen Amtes (PA AA), Länderabteilung III (1920-1936), Persien, R 92541.

72 N.A. Gasanov, 'Iz istorii sovetsko-iranskikh druzhestvennykh otnoshenij (1923-1925 gg.)', Uchenye zapiski Azerbajdzhanskogo Gosudarstvennogo Universiteta im. S.M. Kirova, Seria istorii i filosofii 6 (1965): 25-6.

${ }^{73}$ Cyrus Abivardi, Iranian Entomology cit., 2001, p. 534.

${ }^{74}$ Konfrans-e misyûn-e mokhtalat-e Irân o Shuravi baraye davf-e malakh-e Mughân (Tehran: publisher unknown), 1325 (1946): 14-15. 
in Persian Azerbaijan and acted as technical advisors. ${ }^{75}$ In January 1936, the last important conference of the period was organised between the two countries. ${ }^{76}$ The Azeri Narkomzem, Vezirov, headed the Soviet delegation, since the conference took place in Baku. The Persian delegation toured Azerbaijan and bought agricultural machinery, chemical products; and Iranian entomologists travelled to Kirovabad - the new name for Ganja, since 1935 - where they got acquainted with the latest field discoveries. The deputy director for Agriculture, Ahmed 'Adl, told Soviet newspapers of his admiration for the transformation of Soviet Azerbaijan, which he hadn't visited since 1928. He remarked on his interest in Azeri agricultural institutions, notably the Azeri Tropical Institute.

Iranian leaders were evidently lucid about the political motivations for Soviet help. Border authorities were particularly sensitive to the manipulation of locust-control for gaining influence in the country. In some districts of Mugan, Iranian officials complained in 1930 that the digging of anti-locust trenches in Iranian territory had been a Soviet strategy since 1925 to advance their state border. They gave the example of a trench transformed into a permanent canal, cemented and wired, near the village of Hasan Khanly. ${ }^{77}$ More generally, the presence of Soviet experts was inseparable from the fear of Communist penetration. The action of Perskhlopok, since it involved daily contacts with rural masses, caused particular concern to the police. Credits extended to peasants created an economic dependence and a form of loyalty to the Soviet Union, especially in the poorest regions. ${ }^{78}$ This awareness led Iranian leaders to monitor Soviet expeditions on their soil as closely as possible. However, the

${ }^{75}$ British Consulate in Tabriz, Tabriz locust report for June 1930, undated, NHMA, AL/2/100.

76 'Zakonchilas' sovetsko-iranskaja konferentsija po bor'be s saranchej', Bakinskij Rabochij 10 / 4089: 4.

${ }^{77}$ Letter from the Iranian General Staff to the prime minister, 24 farvardin 1309 (13 April 1930), in Mahmud Tâherahmadi, Asnâd-e ravâbit-e Irân o Shuravi (Teheran: Enteshârât-e Sâzemân-e Asnâd-e Melli-e Irân, 1996) p. 170.

${ }^{78}$ Letter from the intelligence department of the Iranian police to the minister of the Interior, 29 behmân 1309 (18 Feb. 1931), ibid, p. 38. 
model for development aid created in the country seemed successful enough to be progressively enlarged across the entire region.

\section{Regionalising environmental cooperation in the 1930s}

Starting from the late 1920s, Soviet authorities entered into a new course of expanding the geographical scope of their antiacridian foreign policy. This policy was conceived, more generally, as a cross-border cooperation on environmental issues. This cooperation was seen as an opportunity to break the international isolation of the Soviet Union and create a network of friendly states. Cooperation with Iran was clearly the most advanced bilateral relation built on this basis. Negotiations with Afghanistan brought less in the way of results, since the Afghan state was in a situation of chronic instability and had practically no state apparatus to deal with agricultural matters. The Soviet Union nonetheless tried to extend the pattern of Soviet-Iranian cooperation to a larger audience by convening an international conference in 1928. In September, in coordination with the ZSFSR and Central Asian republics, the NKID decided to organise by the end of the year an international conference on locust management, with delegates from Turkey, Iran, Afghanistan, Mongolia and Western China. ${ }^{79}$ Preparatory work revealed that the STO's Veterinary Committee and the People's Commissariat for Health were interested in organising their own conference on cross-border struggles with human and animal diseases. It was thus decided by the All-Union Sovnarkom on 22 September 1927 to organise a joint

${ }^{79}$ Under Yang Zengxin and Jin Shuren, Xinjiang was a de facto independent state in the 1920s-1930s, considered as an autonomous diplomatic actor and an important neighbour by the Soviet Union. James A. Millward, Eurasian Crossroads. A History of Xinjiang (New York: Columbia University Press, 2007) pp. 186-7; for the Mongolian situation, see Elena Boikova, 'Aspects of Soviet-Mongolian Relations, 1929-1939', in Stephen Kotkin and Bruce A. Elleman (eds) Mongolia in the Twentieth Century. Landlocked Cosmopolitan, pp. 107-122 (Armonk-London: M.E. Sharpe, 1999). 
conference on agricultural and sanitary issues. ${ }^{80}$ The Transcaucasian representation in Moscow manifested from the very beginning its interest and willingness to take an active share in the process, since it was directly involved with issues to be addressed. The conference was finally scheduled for March 1928, with an All-Union funding and the participation of both central and republican representatives ${ }^{81}$.

On16 December 1927, the Russian Narkomzem defined as follows the issues to be settled at the conference:

1) Coordination of measures taken to fight against cotton pests, in particular the quarantine to prevent the introduction of cotton parasites and diseases into USSR, 2) Organisation of the struggle against locusts in border regions, 3) Project of a general quarantine to prevent the introduction of plant parasites and diseases into USSR. ${ }^{82}$

The conference thus suggested a geographical extension of crossborder collaborations, as well as an extension to the wider problem of plant protection. By doing so, Soviet authorities entered a new field of international relations, launched by the Rome conference on plant pathology in $1914 .^{83}$ This issue was of particular interest to the Transcaucasian federation, directly concerned by border quarantines on cotton and other agricultural products. ${ }^{84}$ The persistence

${ }^{80}$ Letter from the Zakpredstavitel'stvo to the Transcaucasian Sovnarkom, 2 Feb. 1928, SUITsA, f. 617, op. 1, d. 2331, 1l. 1-3.

${ }^{81}$ Correspondence of the All-Union Sovnarkom on granting 8,000 rubles for the conference, GARF (Gosudarstvennyj arkhiv Rossijskoj Federatsii, Moscow), f. P5446, op. 10, d. 1399, 1l. 1-5; Protocol No. 161 of the All-Union Sovnarkom, 5 Mar. 1928, SUIYA, f. 617, op. 1, d. 2331, 1. 31.

${ }^{82}$ Letter from the Zakpredstavitel'stvo to the Transcaucasian Sovnarkom, 2 Feb. 1928, SUITsA, f. 617, op. 1, d. 2331, 11. 2-3.

${ }^{83}$ Stéphane Castonguay, 'Biorégionalisme, commerce agricole et propagation des insectes nuisibles et des maladies végétales: les conventions internationales phytopathologiques, 1878-1929', Ruralia 16/17 (2005), online; for the scientific basis of this new interest, see W.A. Orton and R. Kent Beattie, 'The Biological Basis of Foreign Plant Quarantines', Phytopathology 13 / 7 (July 1923): 295-306.

${ }^{84}$ An Interdepartmental Commission on the cotton quarantine was created in May 1927 by the STO. A.M. Panteleev, 'Organizatsija karantina po nedopushcheniju zanosa inozemnykh vreditelej khlopchatnika v SSSR', Khlopkovoe delo 12 (Dec. 1929): 1437-55. 
of strong economic links with Eastern Anatolia, which had been included in the Tsarist Empire from 1878 to 1921, and where numerous plant diseases were rife, created an urgent need for border control. ${ }^{85}$ In 1927-1928, for instance, Transcaucasian leaders were preoccupied with the diffusion of the pink bollworm (Pectinophora gossypiella), a cotton pest, in the Igdyr region. An Armenian entomologist, Dekomidov, was dispatched in early 1928 to this area, but came to no clear conclusion as to the necessity of a quarantine. ${ }^{86}$ Measures to check imported cotton at Markara and Leninakan were implemented in March. By May, it was clear that the pink bollworm had caused ravages in the region and an internal quarantine was implemented behind the Soviet border. Cotton could be imported but not moved beyond the border region, so as not to contaminate Caucasian cotton fields in Armenia and Nakhichevan.

At the conference, the majority of official speeches and reports were made by representatives of central institutions, such as the Russian Narkomzem and the State Institute of Experimental Agriculture. One report was entrusted to a republican delegate. Zakhar Rodionov, head of the Entomological Experimental Station in Azerbaijani Mugan from 1920 to 1927, talked about management of cotton pests. This speech built upon a book he had just published, where he demonstrated the similarity between challenges set to Persia and Southern Soviet republics in the culture of cotton. ${ }^{87}$ The report was to be prepared in coordination with the head of the Turkmen Office for Plant Protection, Morits. ${ }^{88}$ Generally speaking, the influence

${ }^{85}$ Candan Badem, Çarlık Rusyası Yönetiminde Kars Vilayeti (Istanbul: Birzamanlar Yayıncilık, 2010); Georg Kobro, Das Gebiet von Kars und Ardahan: Historisch-landeskundliche Studie zu einer Grenzregion in Ostanatolien (Munich: Slavica, 1989); Ararat Hakopjan, Karsi marz: gjughatsiutjan patmutjan urvagtser 1878-1917 t't' (Erevan: Djartaraget, 2000).

${ }^{86}$ Protocol No. 13, Interdepartmental Commission of the Glavkhlopkom on the cotton quarantine, 19 Mar. 1928, SUITsA, f. 617, op. 1, d. 2331, 1. 33.

${ }^{87}$ Zakhar Rodionov, Vrediteli khlopchatnika v Persii (Moscow, Biblioteka Khlopkovogo Dela, 1928).

${ }^{88}$ Letter from the Zakpredstavitel'stvo to the Transcaucasian Sovnarkom, 2 Feb. 1928, SUITsA, f. 617, op. 1, d. 2331, 1. 3. 
of Transcaucasian institutions in the preparation for the conference was felt in an effort to concentrate debates on cross-border cooperation with neighbouring countries. The ministry of Foreign Affairs had made clear that the number of topics addressed and demands should be reduced to a minimum in order to obtain satisfaction. Consequently, everyone tried to push their own interests. ${ }^{89}$ During the conference, the main role fell to the Commissariat for Foreign Affairs, which had been entrusted with the task of submitting to each Oriental delegation two draft conventions on cotton quarantine and on cross-border cooperation for locust management. ${ }^{90}$

This conference on area-wide pest management reflected Soviet preferences by insisting on cotton, so central to the nascent Soviet industry and perhaps even more to the Soviet propaganda that created a myth around this crop that turned desert into lands of plenty. ${ }^{91}$ The Transcaucasian Regional Committee edited a secret booklet on the culture of cotton as a state priority in $1930 .{ }^{92}$ It also fit into a global context of transnational collaboration against the locust threat. Better scientific understanding of the migratory phenomenon was part of the explanation for this turn, which was expressed in publications that stressed the newly understood continental nature of the threats and required international mechanisms of action. ${ }^{93} \mathrm{~A}$ second

${ }^{89}$ Letter from the Georgian Commissar for Agriculture, Gegechkori, to the Russian Narkomzem, 14 January 1928, SUITsA, f. 617, op. 1, d. 2331, 1. 28.

${ }^{90}$ Secret supplement to the Protocol No. 268 of the All-Union Sovnarkom, 3 July 1928, SUITsA, f. 616, op. 1, d. 2, 11. 306-310.

${ }^{91}$ Adrienne Lynn Edgar, Tribal Nation. The Making of Soviet Turkmenistan, pp. 206-7 (Princeton: Princeton University Press, 2006) pp. 206-7; Beatrice Penati, 'Le comité du coton et les autres. Secteur cotonnier et pouvoir économique en Ouzbékistan, 1922-1927’, Cahiers du monde russe 52 / 4 (2011): 555-589.

${ }_{92}$ The ZSFSR, above all Azerbaijan and Nakhichevan, was admittedly only the second production area for cotton in the Soviet Union, behind Central Asia. SUITsA, f. 616, op. 1, d. 5, 11. 240-256.

${ }^{93}$ Paul Vayssière, 'Le problème acridien et sa solution internationale', Matériaux pour l'étude des calamités possibles 2 (Genève: Société de Géographie, 1924):, 122-158; the first anti-acridian and phytopathological regional organisation was the Defensa agricola created in 1913 among between Chile, Brazil, Argentina and Uruguay: Informe de los trabajos de la Conferencia internacional de la Defensa Agrícola en Montevideo, (Asunción, 1913). 
explanation could be linked to the involvement of France and GreatBritain in former Ottoman regions. These regions, together with the Arabic Peninsula and Iran, were a corridor for locust migrations at the crossroads between Asia, Eastern Europe, the Mediterranean and Africa. For the British Empire, in particular, joint locust management was a way to express concretely common goals from Delhi to Lagos, at a time when imperial unity was seen as threatened. ${ }^{94}$ The Imperial Bureau of Entomology, created in 1913, played a key role in the 1910s-1920s in intra-imperial coordination and information exchange..$^{95}$ Great-Britain and France actually spurred their mandates in the Middle East to enter an agreement on locust control. On 20 May 1926, a treaty was signed between Syria, Jordan, Iraq, Palestine and Turkey to create an International Office for Information Regarding Locusts (Office international de renseignement sur les sauterelles), based in Damas. ${ }^{96}$ A few years later, in March 1931, Persia announced its adhesion to the Office. ${ }^{97}$ All these developments were part, in Soviet interpretations, of the general imperialist plot to contain communism in the region and organise counter-revolution in the Caucasus.

In the early 1930s, this general interest in bilateral or imperial cooperation evolved toward attempts at wider multilateral manage-

${ }^{4}$ John Darwin, The Empire Project. The Rise and Fall of the British World System, 1830-1970 , pp. 419-75 (Cambridge-New York: Cambridge University Press, 2009) pp. 419-75 ; Antonio Buj, 'International Experimentations and Control of the Locust Plague - Africa in the First Half of the 20 20 th CCentury', in Yvon Chatelin and Christophe Bonneuil (eds.), Les sciences hors d'Occident au XX' siècle, Vol. 3 : Nature et environnement, pp. 93-105 (Paris: Orstom Editions, 1995) pp. 93-105.

${ }^{95}$ C. Gordon Hewitt, 'The Imperial Bureau of Entomology', The Canadian Entomologist. 45 /, 6 (June 1913): 171-174; C. Gordon Hewitt, 'A Review of Applied Entomology in the British Empire', Annals of the Entomological Society of America IX / 1 (, Vol. IX, No. 1, March 1916, pp.): 3-34.

${ }^{6}$ Ahmet Gündüz Ökçün and, Ahmet R. Ökçün, Türk antlaşmaları rehberi (1920-1973) , p. 145 (Ankara: Ankara Universitesi Siyasal Bilgiler Fakültesi Yayınları, 1974) p. 145 ; Jean-David Mizrahi, Genèse de l'Etat mandataire. Service des Renseignements et bandes armées en Syrie et au Liban dans les années 1920 , p. 175 (Paris: Publications de la Sorbonne, 2003) p. 175.

${ }^{97}$ Letter from the Persian consul-general in Beyrut to the president of the Office, 12 March Mar. 1931, NHMA, AL/1/6. 
ment. A parallel evolution could be observed in Soviet diplomacy. The concomitance between Western and Soviet initiatives was probably rooted in the Soviet unwillingness to concede a monopoly to a British-dominated locust management system. It should also be recalled that the USSR surreptitiously renounced its categorical hostility to multilateralism by joining the League of Nations in $1934 .{ }^{98}$ This system would have embraced all states located south of the Soviet Union, in the Middle East and Central Asia. At a time when relations with Great-Britain remained conflicted and the imminence of an imperialist war was emphasised, it would have been nefarious to leave such an important matter to hostile powers. As international locust cooperation was essentially an inter-imperial cooperation, it could not be accepted by the Soviet Union. The first international conference on locust management was held in Rome in September-October 1931, on a joint Italian and British initiative. ${ }^{99}$ This conference confirmed Soviet apprehensions, by selecting the Imperial Bureau of Entomology - soon to become the Imperial Institute of Entomology - as the hub for information exchange in the field. Several conferences were held later in the 1930s: July 1932 in Paris, September 1934 in London, April 1936 in Cairo and September 1938 in Brussels. The Soviet Union took part in none of them.

In January 1933, Soviet authorities communicated to the Afghan and Iranian governments their willingness to sign bilateral locust conventions, since the 1928 conference had not been successful in this respect. ${ }^{100}$ This diplomatic démarche followed a decision by the

${ }^{8}$ Sabine Dullin, Des hommes d'influence. Les ambassadeurs de Staline en Europe, 1930-1939 (Paris: Payot, 2001).

${ }^{99}$ The Italian Ministry of Colonies, due to its presence in Libya, Eritrea and Italian Somalia, was plunged into the Middle Eastern migration area of locusts, which explained its interest for in the problem in during the 1930s:. Giulio Trinchieri, Secondo Contributo alla bibliografia delle cavallette (Rome: Istituto Poligrafico dello Stato, 1933); Anonymous, 'La lotta contro le cavallette in Eritrea e la conferenza intercoloniale di Chartum', Rassegna Economica delle Colonie 7-8 (1929): 3-33.

${ }^{100}$ Letter from to the Soviet ambassador in Kabul, Stark, to the Afghan Foreign Minister, Faiz Muhammad Khan, F.P. Polia et al. (eds) Dokumenty vneshnej politiky SSSR, Vol. 15, (Moscow, Gospolitizdat, 1970)F.P. Polia et alii (eds.), DVP SSSR, Vol. 15, 1970, pp. 28-29. 
All-Union Sovnarkom, on 11 July 1932. ${ }^{101}$ The object of the convention was seemingly clear: it was to fix once and for all the conditions of cross-border anti-acridian cooperation. The Soviets wanted to dispense with tedious annual negotiations about these conditions. Signatory states committed to anti-locust actions and mutual information and each gave access to the counterpart's anti-acridian teams in case they could not deal independently with the locust threat. Each state should finance works undertaken on its own soil, even if they were performed by experts from the other state. This was a clear departure from anterior practices, when the Soviet Union had funded a large part of locust operations in Persia and Afghanistan. Whereas Soviet diplomats could propose sufficient incentives to Afghanistan and had the political clout to force the convention upon an utterly weak state, ${ }^{102}$ Iran resisted the adoption of such a convention until August $1936 .{ }^{103} \mathrm{~A}$ probable fear was the loss of sovereignty entailed by the convention, which set a strict schedule for operations and numerous obligations for information exchange. The convention created a potential risk of unwanted intrusion by Soviet expeditions and locust teams. Iranian leaders were growing ever wearier about Soviet interventions in the country since the former OGPU agent Agabekov had revealed how deeply Soviet intelligence services had colonised the Iranian higher administration. ${ }^{104}$ Large numbers of Soviet citizens had fled the USSR as a result of collectivisation and lived in Northern Iran since 1929, creating an overall hostile mood to the communist regime. This explained a certain reluctance to admit massive locust expeditions in Persia.

${ }^{101}$ M.A. Sivolobov (ed.), DVP SSSR, Vol. 17, 1971, p. 832.

102 See the text of the convention, signed on 6 May 1935, in Sobranie zakonov SSSR, Section I, No. 16, 1 October 1935, pp. 255-258.

${ }^{103}$ Letter from Karakhan to Pastukhov, 2 August Aug. 1933; F.P. Polia et al. (eds.), Dokumenty vneshnej politikyDVP SSSR, Vol. 15, 1970, Moscow, Gospolitizdat, 1970, pp. 474-476; British Legation in Tehran to the Foreign Office, 20 February Feb. 1936, NHMA, AL/2/100.

${ }^{104}$ Taline Ter-Minassian, Colporteurs du Komintern. L'Union soviétique et les minorités au Moyen-Orient, pp. 142-4 (Paris: Presses de la Fondation Nationale des Sciences Politiques, 1997) pp. 142-4. 

the Trustees of the Natural History Museum

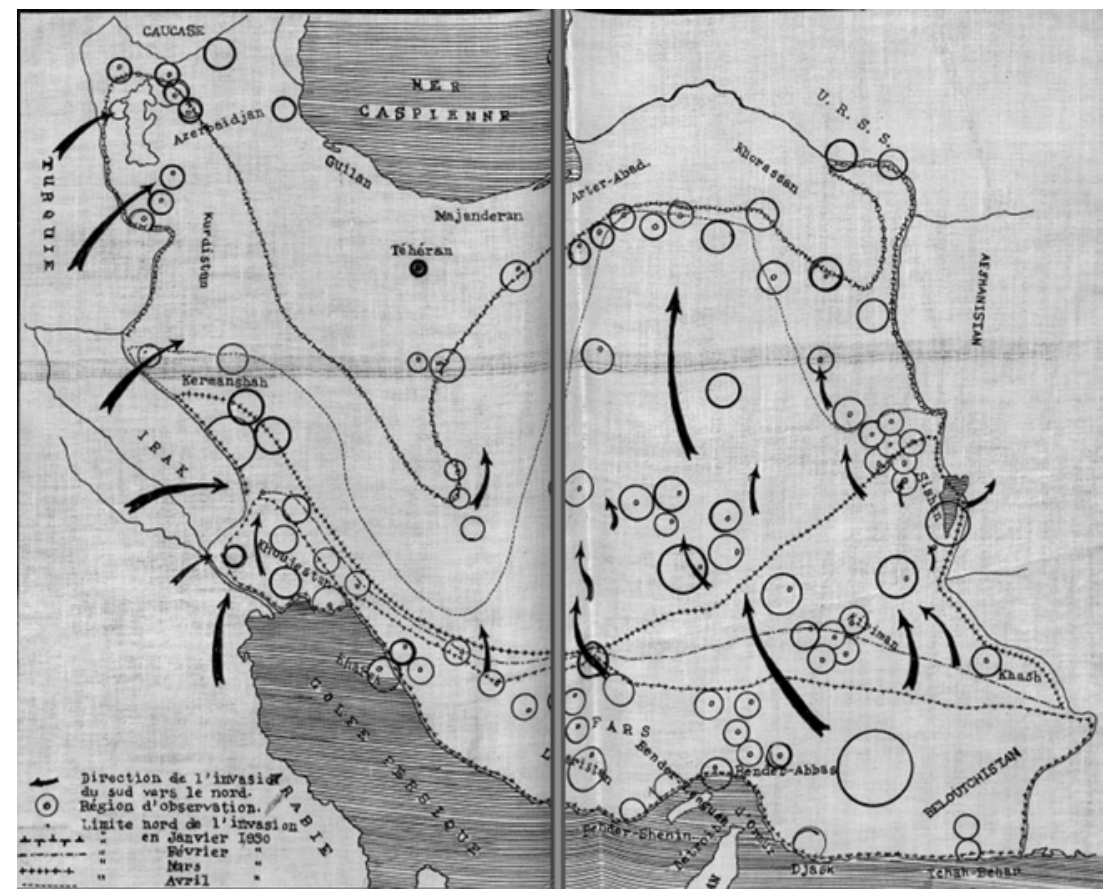

Evolutions in Soviet locust diplomacy in the 1930s have to be connected to an important scientific debate that stirred academic circles in the country. Since the late 1920s, a new acridian species had come to the forefront as perhaps the most dangerous and virulent, the Schistocerca gregaria Forsk. ${ }^{105}$ Activity cycles had already happened in 19001904 and 1911-1916, but a violent outburst occurred in 1925-1931, in the Middle East, Iran and Southern Soviet republics. ${ }^{106}$

${ }^{105}$ F.S. Bodenheimer and, G. Fraenkel, 'Studien zur Epidemiologie, Ökologie und Physiologie der afrikanischen Wanderheuschrecke (Schistocerca gregaria Forsk.)', Zeitschrift für angewandte Entomologie, B. 15 / , H. 3, pp.: 435-457.

${ }^{106}$ Protocol No. 127 of the Transcaucasian Sovnarkom, SUITsA, f. 617, op. 1, d. 4979, 1. 21. 
In London, the Imperial Bureau of Entomology pioneered research on this new species and its geographical area, as numerous British regions were concerned. The extensive consular network in Persia and the Perso-Arabic Gulf was put to use, as well as connections with the Persian administration. ${ }^{107}$ In 1929, Uvarov agreed to write a general brochure on the Schistocerca and opened a debate on its geographical origin. ${ }^{108} \mathrm{He}$ considered this locust to be endogenous in southern Persia, notably Beluchistan and Farsistan. It then migrated northward to the Soviet Union. His opinion was supported by an expedition made in Eastern Iran in 1930-1931 by Professor Predtechenskij, who described the life cycle of the Schistocerca. It nested in Southern Iran, where annual average temperatures hovered around 24-27 degrees Celsius. Its migration started in February and Schistocerca swarms followed vegetation areas, since they needed food on the road. Four main roads could be distinguished, with a major corridor in the Karun valley to Persian and Soviet Azerbaijan. ${ }^{109}$ The opinion that Schistocerca was a purely Iranian phenomenon was not entirely shared among Soviet, Iranian and British scientists. ${ }^{110} \mathrm{~N}$. Shcherbinovskij was the fiercest opponent of this thesis and developed a theory of migrations on a continental scale. According to him, conditions for the massive reproduction of locusts existed only in the Arabic Peninsula, British India and Eastern Africa. His opinion, in the 1930s, was still a minority one and could hardly compete with the combined prestige of Uvarov and Predtechenskij. Nonethe-

${ }^{107}$ Letter from Ahmed 'Adl to Boris Uvarov, Teheran, 10 May 1930, NHMA, $\mathrm{AL} / 2 / 100$.

108 Boris Uvarov, Pustynnaja sarancha Shistocerca gregaria (Moscow: Gostekhizdatel'stvo, 1929).

109 S. Predtechenskij, 'Pustynnaja sarancha v Persii (Schistocerca gregaria Forsk)', Sbornik Vsesojuznogo Instituta zashchity rastenij, No. 4, pp.4: 72-76 (Leningrad: VIZR, 1932); see also S. Predtechenskij, 'Materialy po izucheniu pustynnoj saranchi v Srednej Azii i Zakavkaz'e v 1929-1930 gg.', Trudy po zashchite rastenij, Vol. 11, (1935):, pp. 1-91.

110 The original Iranian position is summed up in a memorandum of the Persian Ministry for Foreign Affairs to the British legation, Teheran, 22 October 1929, NHMA, AL/2/100. See also D.P. Dovnar-Zapolsky, Data on the biology of the Schistocerca Gregaria Forsk, 3 October 1930, NHMA, AL/2/100. 
less, the debate between Shcherbinovskij and his illustrious predecessors was broached at a trilateral conference between the USSR, Iran and Turkey, held in Moscow in July 1930, where the geographical scope of the Schistocerca was addressed. ${ }^{111}$ Shcherbinovskij eventually succeeded in disseminating his ideas in the late 1930s and used the Soviet occupation of Iran after 1941 to test his theory and document it. After World War Two, it became the official doxa on Schistocerca migratory trajectories and legitimated the new course in Soviet locust diplomacy. This new scientific doctrine was in line with the now-global ambitions of the Soviet Union and its willingness to provide development aid to a wide range of countries in Africa, the Middle East and the Indian sub-continent.

\section{Conclusion}

The question of the origins of development policies remains a controversial one, and different genealogies have been mentioned. The gradual transition from development programmes in interwar colonial empires to development aid after decolonisation is emphasised, as a stain upon the very concept of development aid. ${ }^{112}$ The North-American genealogy points to the role of private foundations and endowments in the 1920s-1930s. ${ }^{113}$ However, these genealogies cannot explain the evolution of Soviet foreign aid. The Cold War context obviously accounts for the tremendous rise in development assistance in the Third World. However, this connection should not erase, in our view, the weight of interwar experiences. The Soviet engagement with the acridian threat demonstrates the way first at-

111 'Sovetsko-turetsko-persidskaja konferentsija po bor'be $s$ vrediteljami sel'skogo khozjajstva', Zarja Vostoka 193, 2461 (21 July 1930): 1.

${ }_{112}$ Barry Ireton, Britain's International Development Policies. A History of DFID and Overseas Aid (Basingstoke-New York: Palgrave-Macmillan, 2013).

${ }^{113}$ Steven Paul Palmer, Launching Global Health: The Caribbean Odyssey of the Rockfeller Foundation (Ann Arbor: The University of Michigan Press, 2010); William H. Schneider (ed.), Rockfeller Philanthropy \& Modern Biomedicine. International Initiatives from World War One to the Cold War (Bloomington: Indiana University Press, 2002). 
tempts were made at knowledge-transfer and aid in the field of environmental and sanitary policies at the time. The peculiarity of this Soviet assistance is to overlap internal and external concerns. Actually, the modernisation promoted by Soviet authorities happened simultaneously in the Soviet republics of the Caucasus and Central Asia and in Middle Eastern or Asian countries bordering on the USSR. This gave an opportunity to present Soviet cooperation as a 'brotherly help' and not as an imposition from the West. This factor explains the role played by Caucasian and Central Asian institutions in the process. Their cultural and regional expertise was considered an asset and Transcaucasian authorities were particularly keen to play an active role in the field. Progressively, the field of action was extended and, by the end of the 1930s, one can observe the first signs of Soviet claims to environmental cooperation extending to the entire Middle East. Scientific advance had its share in this evolution, since it seemed to confirm the continental range of Schistocerca locust invasions. The Soviet example thus demonstrates a similar tension between the apparently objective dimension of environmental management and its highly political message, embodying a vision of what modernity means. 